\title{
PENYEBAB KONFLIK ANTARA PENGIKUT GERAKAN FAJAR NUSANTARA (GAFATAR) DAN MASYARAKAT MEMPAWAH TIMUR
}

\author{
Hasan Almutahar \\ Fakultas Ilmu Sosial dan Ilmu Politik Universitas Tanjungpura \\ E-mail: hasanalmutahar4@gmail.com
}

\begin{abstract}
ABSTRAK. Tujuan penelitian ini adalah menganalisa penyebab konflik antara Gerakan Fajar Nusantara (Gafatar) dengan masyarakat Mempawah Timur. Penyebab terjadinya konflik dikarenakan masyarakat Mempawah Timur menganggap kelompok Gafatar memiliki pola kehidupan yang tidak wajar. Jenis penelitian ini adalah kualitatif, teknik pengumpulan data dengan menggunakan teknik wawancara dan studi literatur berupa koran, buku dan jurnal. Berdasarkan hasil penelitian terdapat tiga bentuk penyebab terjadinya konflik yaitu adanya indikasi penyimpangan ajaran agama yang tidak sesuai dengan kebenaran ajaran agama, adanya indikasi penyimpangan administrasi kependudukan karena tidak mengikuti prosedur sebagaimana ketentuan proses administrasi negara yang berlaku dan adanya indikasi penyimpangan struktur pemerintahan dalam pembentukan Rencana Bagan Struktur Dewan Pimpinan Daerah secara tersendiri oleh kelompok Gafatar yang semakin menyebabkan masyarakat Mempawah Timur menolak keberadaan kelompok Gafatar.
\end{abstract}

Kata kunci: gerakan fajar nusantara, menolak, konflik

\section{CAUSES OF CONFLICT BETWEEN GERAKAN FAJAR NUSANTARA (GAFATAR) AND COMMUNITY OF EAST MEMPAWAH}

\begin{abstract}
The purpose of this study is to analyze the cause of conflict between the Gerakan Fajar Nusantara (Gafatar) with community of East Mempawah. The causes of conflict because the community of East Mempawah considers the Gafatar group has a pattern of unnatural life. The research is a qualitative, data collection techniques using literature study and interview techniques in the form of newspapers, books and journals. According to the research, there are three forms of the causes of conflict they are is indications of irregularities religious teaching that does not correspond to the truth of religious teachings, beside that indications of irregularities in the administration of residence because they do not follow the procedures as set forth administrative process applicable state and indications of irregularities governance structures in the formation Plan Structure Chart Regional Executive Board separately by Gafatar group increasingly caused people refused the existence of the Gafatar group.
\end{abstract}

Key words: Gerakan Fajar Nusantara, refused, conflict

\section{PENDAHULUAN}

Gafatar adalah kelompok gerakan sosial dengan membawa ajaran menyimpang atas dasar agama dan merupakan hasil dari ajaran Millah Abraham. Kelompok Gafatar menggencarkan kegiatan sosial misalnya pengadaan donor darah, dan memaksimalkan potensi pertanian dengan tujuan mendapatkan perhatian dari pihak lain agar tertarik untuk mengikuti ajaran Gafatar. Pemimpin Gafatar bernama Achmad Musahddeq yang menanggap dirinya sebagai nabi yang mendapatkan wahyu atas kebenaran ajarannya (Direktur Pembinaan Masyarakat Kepolisian Daerah Kalimantan Barat, 2016: 1). Kelompok Gafatar tersebut menyebar ke wilayah Kalimantan barat dalam menjalankan aktivitas sosialnya. Kegiatan sosial yang dilakukan kelompok gafatar mendapatkan penolakan masyarakat dari salah satu wilayah persebaran kelompok gafatar karena dianggap menyimpang. Wilayah yang tersebut adalah Kabupaten Mempawah Timur Provinsi Kalimantan Barat. Persebaran Kelompok Gafatar di Kalimantan Barat ditampilkan pada tabel 1 berikut ini.
Tabel 1. Persebaran Kelompok Gafatar di Kalimantan Barat

\begin{tabular}{clc}
\hline No & \multicolumn{1}{c}{ Wilayah } & Jumlah Pengikut Gafatar \\
\hline 1 & Kabupaten Ketapang & 1.288 jiwa \\
2 & Kabupaten Mempawah & 1.140 jiwa \\
3 & Kabupaten Melawi & 972 jiwa \\
4 & Kabupaten Kayong Utara & 732 jiwa \\
5 & Kabupaten Kubu Raya & 449 jiwa \\
6 & Kota Singkawang & 302 jiwa \\
7 & Kabupaten Bengkayang & 267 jiwa \\
8 & Kabupaten Sambas & 131 jiwa \\
9 & Kabupaten Sintang & 131 jiwa \\
10 & Kabupaten Kapuas Hulu & 104 jiwa \\
11 & Kabupaten Landak & 60 jiwa \\
12 & Kabupaten Sanggau & 46 jiwa \\
13 & Kota Pontianak & 22 jiwa \\
\hline & Total & 5.636 jiwa \\
\hline
\end{tabular}

Sumber: Direktur Pembinaan Masyarakat Kepolisian Daerah Kalimantan Barat (2016:9)

Tabel 1 menggambarkan total jumlah anggota Gafatar yang tersebar di Kalimantan Barat sebanyak 5.636 jiwa. Sebagian besar kelompok Gafatar menyebar di wilayah kabupaten. Tiga wilayah dengan penyebaran kelompok Gafatar terbanyak adalah Kabu- 
paten Ketapang sebanyak 1.288 jiwa, di Mempawah dengan jumlah 1.140 jiwa dan di Kabupaten Melawi sebanyak 972 jiwa, sedangkan wilayah penyebaran kelompok Gafatar terendah adalah kota Pontianak dengan jumlah 22 jiwa. Salah satu dari tiga wilayah terbanyak atas penyebaran kelompok Gafatar yang mengalami konflik atas kedatangan Gafatar tersebut adalah wilayah Kabupaten Mempawah. Awal mulanya, kedatangan kelompok Gafatar diterima secara baik oleh pemerintah dan masyarakat di daerah Mempawah. Kelompok Gafatar memiliki tujuan untuk menjalankan kegiatan sosial khususnya dalam mengoptimalkan pertanian. Penerimaan kelompok Gafatar ditunjukkan dengan penyediaan tempat tinggal mereka saat belum memiliki hunian. Warga sekitar mengizinkan kelompok Gafatar mengontrak di tempatnya. Warga di wilayah tersebut telah menunjukkan kepeduliannya terhadap kelompok Gafatar. Tidak lama kemudian kelompok Gafatar mendirikan tempat tinggal dalam suatu wilayah perkumpulan yang tertutup dari lingkungan masyarakat disekitarnya. Masyarakat sekitar mulai mencurigai keberadaan kelompok Gafatar karena dianggap telah mengasingkan diri. Selain itu kebiasaan kelompok Gafatar dalam bertani/bercocok tanam dinilai berbeda dengan petani lainnya. Sebelum memulai kegiatan bertani kelompok Gafatar melaksanakan apel terlebih dahulu, selain itu mereka tidak menjalankan kewajiban mereka sebagai pemeluk agama Islam misalnya tidak pernah menjalankan Shalat Jumat di masjid padahal dari kartu indentitas mereka berstatus agama Islam (Direktur Pembinaan Masyarakat Kepolisian Daerah Kalimantan Barat, 2016: 15).

Kejanggalan-kejanggalan tersebut menimbulkan konflik yang terjadi antara masyarakat sekitar dan kelompok Gafatar. Masyarakat memberi batas selama 3 hari kepada kelompok Gafatar untuk keluar dari daerah tersebut namun tidak di respon oleh kelompok Gafatar sehingga emosi masyarakat semakin tidak terkontrol. Peringatan yang diabaikan oleh kelompok Gafatar membuat kericuhan pada tanggal 19 Januari 2016 dengan tujuan pengusiran kelompok Gafatar untuk kembali ke daerah asalnya. Kemarahan massa berujung pada aksi anarkis warga Kabupaten Mempawah dengan membakar pemukiman dan mobil milik kelompok Gafatar (Koran Media Indonesia, 2016: 7). Berdasarkan fenomena terjadinya konflik kelompok Gafatar, peneliti tertarik melakukan penelitian yaitu penyebab terjadinya konflik antara kelompok Gafatar dan masyarakat Mempawah Timur.

\section{METODE}

Metode yang digunakan dalam penelitian ini adalah kualitatif-deskriptif. Teknik pengumpulan data dengan menggunakan teknik wawancara dan teknik dokumentasi dan, studi literatur berupa koran, buku dan jurnal. Peneliti melakukan wawancara dengan Komandan Distrik Militer, Kepala Kepolisian Resor Kalimantan Barat, 6 anggota Gafatar dan 4 orang masyarakat Kabupaten Mempawah dengan bantuan pedoman wawancara yang telah disusun sesuai dengan pertanyaan yang berkaitan dengan penelitian. Hasil wawancara dan studi literatur dilanjutkan dengan menganalisis data untuk menemukan hasil penelitian.

\section{HASIL DAN PEMBAHASAN}

\section{Adanya Indikasi Penyimpangan Ajaran Agama}

Proses hubungan yang terjadi di masyarakat terbagi menjadi dua bentuk yaitu proses assosiatif dan proses dissosiasif. Proses assosiatif adalah bentuk hubungan masyarakat yang mengarah pada persatuan dan kebersamaan sedangkan proses dissosiasif adalah bentuk hubungan masyarakat yang mengarah pada perpecahan. Proses dissosiasif membuka peluang terjadinya pertikaian baik dalam bentuk individu maupun kelompok (Retnowati, 2014: 190). Pertikaian antar kelompok atas dasar agama disebabkan oleh adanya perselisihan cara pandang kelompok satu dengan kelompok lain karena adanya anggapan unsur penyimpangan atas aliran ajaran agama (Lay, 2009: 5).

Berdasarkan hasil rapat kerja nasional tahun 2007, MUI telah memutuskan 10 karakteristik ajaran menyimpang. Adapun kriteria tersebut meliputi: 1) tidak mengakui Rukun Iman dan Islam; 2) percaya bahwa ada wahyu lain setelah Al Quran; 3) meragukan kebenaran Al Quran; 4) menterjemahkan Al Quran tanpa berpatokan pada kaidah tafsir; 5) memungkiri Hadits nabi sebagai pedoman agama Islam; 6) tidak memuliakan nadi dan rasul; 7) tidak mengakui nabi Muhammad sebagai nabi dan rasul terakhir; 8) merubah ketentuan ibadah berdasarkan syariah; 9) menganggap muslim yang tidak mengikuti ajarannya adalah kafir; 10) tidak mempercayai bahwa aqidah berdasarkan dalil Syar'I (Direktur Pembinaan Masyarakat Kepolisian Daerah Kalimantan Barat, 2016 : 17).

Hasil penelitianmenunjukkan bahwaaliran Gafatar termasuk sebagai aliran yang menyimpang dari agama Islam. Mereka tidak menjalankan kewajiban sebagaimana ajaran agama Islam seperti, tidak melaksanakan ibadah 5 waktu, tidak berpuasa Ramadhan, menterjemahkan AlQuran dengan pemahaman sendiri serta mengucapkan kalimat syahadat yang berlainan dan menganggap kafir ajaran lain. Ajaran kelompok Gafatar memiliki dua jenis ibadah. Pertama, ibadah yang dilakukan pada pukul 01.00 sampai 04.00 dengan jumlah rakaatnya ganjil sebanyak 11 rakaat dalam hitungan sekali ibadah sehari. Kedua, ibadah dalam bentuk berbuat baik dan menghindari kebohongan. 


\section{Adanya Indikasi Penyimpangan Administrasi Kependudukan}

Konflik terjadi karena adanya perbedaan tujuan yang ingin dicapai antar pihak-pihak yang memiliki kepentingan secara individu maupun kelompok (Sahlan, 2012: 93). Tidak jarang konflik yang muncul di lingkungan masyarakat dikarenakan adanya unsur penyimpangan. Sebagaimana kelompok Gafatar, selain di anggap menyimpang dari ajaran agama, kelompok Gafatar juga termasuk menyimpangan dari administrasi kependudukan.

Hasil penelitian menunjukkan bahwa pengakuan kelompok Gafatar terkait pembubaran organisasinya berbanding terbalik dengan kenyataan yang terjadi di lapangan. Hal tersebut dibuktikan dengan adanya penemuan dokumen-dokumen milik kelompok Gafatar salah satunya berupa Kartu Keluarga Gafatar berlambang Gafatar, namun bukan berlambang Garuda. Kartu Keluarga Gafatar dikeluarkan oleh Struktur Dewan Pimpinan Daerah yang dibentuk oleh kelompok Gafatar. Kelompok Gafatar mengaku sudah membubarkan organisasinya, namun berdasarkan bukti yang ada kelompok Gafatar masih tetap mendirikan struktur kepengurusan secara tersendiri dalam administrasi penduduk yang menunjukkan bahwa kelompok Gafatar masih tetap aktif menjalankan organisasinya. Disinyalir aktifitas kelompok Gafatar yang masih berlanjut dikarenakan kelompok gafatar telah mengorbankan seluruh harta bendanya yang habis terjual untuk membeli lahan pertanian dan menjadi pengikut kelompok Gafatar. Apabila pembubaran kelompok Gafatar dilaksanakan maka kelompok tersebut merasa tidak memiliki arah tujuan.

\section{Adanya Indikasi Penyimpangan Struktur Pemerintahan}

Pemerintah merupakan sipil yang memiliki kewenangan dan kekuasaan untuk mengatur negara (Legowo, 1999: 79). Negara membentuk struktur pemerintahan dalam menjalankan sistem pemerintahan untuk memimpin rakyat. Pada kenyataannya kelompok Gafatar tidak mengikuti sistem pemerintahan Negara Indonesia dengan membentuk stuktur pemerintahan baru.

Lebih Lanjut hasil penelitian menunjukkan bahwa kelompok Gafatar terindikasi melakukan sistem pemerintahan tersendiri secara illegal atas pembentukan Rencana Bagan Struktur Dewan Pimpinan Daerah kelompok Gafatar. Struktur kepengurusan secara tersendiri ditandai dengan pembentukan Struktur Dewan Pemerintahan Daerah yang dijabat oleh kelompok Gafatar dan juga dipilih oleh kelompok Gafatar. Kelompok Gafatar juga memasuki wilayah Kalimantan barat secara ilegal dengan sembunyi-sembunyi tanpa melalui proses dan prosedur administrasi kependudukan Negara Indonesia karena kelompok tersebut memiliki anggapan telah memiliki sistem pemerintahan sendiri. Sehingga semakin jelas bahwa kelompok Gafatar melakukan penyimpangan dari sistem pemerintahan Negara Indonesia bandingkan dengan Cornelis, 2009.

\section{SIMPULAN}

Berdasarkan hasil pembahasan mengenai konflik yang terjadi antara kelompok Gafatar dengan masyarakat Kabupaten Mempawah Timur, terdapat tiga penyebab terjadinya konflik yaitu 1) aliran Gafatar termasuk sebagai aliran yang menyimpang dari agama Islam berupa ajaran tidak melaksanakan ibadah lima waktu, tidak berpuasa Ramadhan, menterjemahkan Al-Quran dengan pemahaman sendiri serta mengucapkan kalimat syahadat yang berlainan dan menganggap kafir ajaran lain; 2) adanya indikasi penyimpangan administrasi kependudukan berupa penemuan Kartu Keluarga Gerakan Fajar Nusantara berlambang Gafatar yang dikeluarkan oleh Struktur Dewan Pimpinan Daerah dan dibentuk oleh kelompok Gafatar; 3) adanya indikasi penyimpangan struktur pemerintahan berupa pembentukan Rencana Bagan Struktur Dewan Pimpinan Daerah kelompok Gafatar yang dijabat oleh kelompok Gafatar dan juga dipilih oleh kelompok Gafatar.

\section{DAFTAR PUSTAKA}

Lay, C. 2009. Kekerasan Atas Nama Agama: Perspektif Politik. Jurnal Ilmu Sosial dan Ilmu Politik, 13 (1), 1-19.

Legowo, T.A. 1999. Persepsi Militer Terhadap Peran LSM: Penyelesaian atau Masalah. Sukma, Rizal dan Kristiadi J (Ed). Jakarta: Centre For Strategic and Internasional Studies.

Retnowati. 2014. Agama, Konflik, Dan Integrasi Sosial (Integrasi Sosial Pasca Konflik Situbondo) Jurnal Analisa, 21 (02), 189-200.

Sahlan, M. 2012. Pengamatan Sosiologis Tentang Perceraian Di Aceh. Jurnal Substantia, 14 (1), 88-96.

Direktur Pembinaan Masyarakat Kepolisian Daerah Kalimantan Barat. 2016. Seminar Gerakan Fajar Nusantara (Gafatar) Serta Indikasi Ajaran Millah Abraham. Makalah dipresentasikan dalam kegiatan dialog tohoh agama, diselenggarakan oleh Forum Peduli Ibu Pertiwi dan Yayasan Tunas Karya Nyata Pontianak.

Koran Media Indonesia. 25 januari 2016. Melindungi Warga Negara. 